\title{
Morphological fractions and in vitro fermentation characteristics of five endosperm types maize stover harvested at two maturity stages ${ }^{*}$
}

\author{
S.X. Tang ${ }^{1,2}$, L.X. Sheng ${ }^{1}$, Z.L. Tan ${ }^{1,6}$, G.O. Tayo ${ }^{4}$, H.Y. Liao ${ }^{3}$, \\ Z.H. Sun ${ }^{1,2}$, B. Zeng ${ }^{1,2}$, X.F. Han ${ }^{1}$, C.S. Zhou ${ }^{1}$ and G.P. Ren $^{5}$ \\ ${ }^{1}$ Key Laboratory of Agro-ecological Processes in Subtropical Region, \\ Institute of Subtropical Agriculture, The Chinese Academy of Sciences \\ Changsha, Hunan 410125, P.R. China \\ ${ }^{2}$ Graduate University of Chinese Academy of Sciences \\ Beijing 100049, P.R. China \\ ${ }^{3}$ Mathematics and Science Department, Hunan First Normal College \\ Changsha, Hunan 410002, P.R. China \\ ${ }^{4}$ Babcock University, P.M.B. 21244, Ikeja, Lagos, Nigeria \\ ${ }^{5}$ Hunan Yahua Dairy Industry Co. Ltd. \\ Changsha, Hunan 410005, P.R. China
}

(Received 4 November 2008; revised version 24 February 2009; accepted 24 June 2009)

\begin{abstract}
This study was conducted to estimate the effect of maize endosperm type, e.g., waxy, conventional, fodder, sweet, and high oil, and maturity stage on chemical composition and in vitro fermentation characteristics of morphological fractions. Whole maize stover was separated into four fractions, including leaf blade, leaf sheath, stem and husk. The proportion of leaf blade, leaf sheath and husk, and crude protein $(\mathrm{CP})$ and phosphorus $(\mathrm{P})$ contents decreased, whereas the proportion of stem and fibre content increased with the increasing of maturity stage. High oil, sweet, fodder and conventional had the highest proportion in leaf blade, leaf sheath, stem and husk, respectively. Leaf blade had the highest $\mathrm{CP}$ and $\mathrm{P}$ contents and husk had the highest neutral detergent fibre content. Conventional had the highest $(\mathrm{P}<0.05)$ acid detergent fibre content but the lowest $(\mathrm{P}<0.05) \mathrm{CP}$ content than the others. Fodder and high oil had the highest $\mathrm{P}$ and organic matter $(\mathrm{OM})$ content.
\end{abstract}

\footnotetext{
*Supported by The Chinese Academy of Sciences, No. kscx2-YW-N-022, the Ministry of Science and Technology of China, 2006BAD04A15, and Natural Science Foundation of Hunan Province, No. 05JJ10004

${ }^{6}$ Corresponding author: e-mail: zltan@isa.ac.cn
} 
In vitro gas production parameters of $b, a+b$, in vitro OM disappearance (IVOMD), and concentration of total volatile fatty acid (TVFA) decreased $(\mathrm{P}<0.05)$ with the increase of maturity. Maize stover parts from waxy variety had the highest values of $b, c$ and $a+b$, whereas the morphological fractions from conventional variety had the highest IVOMD. The morphological fractions differed in $c$ value and potential gas production in the following order: husk $>$ leaf sheath $>$ stem $>$ leaf blade. The highest and lowest values of IVOMD were observed in husk and stem, respectively. The highest TVFA concentration, molar proportion of acetate and propionate were noted in high oil, waxy and sweet, respectively. The result indicated that the nutritive value of maize stover could be improved through the selection of endosperm type and appropriate maturity stage.

KEY WORDS: maize stover, genotype, morphological fraction, maturity stage, in vitro fermentation

\section{INTRODUCTION}

Over recent years, many new maize hybrids (such as sweet maize, waxy maize, high oil maize and fodder maize) have been developed to supply fresh maize grain for human consumption and to supply feed for livestock. The byproducts from maize grain processing or maize stover after maize grain harvested are one of the most important sources of feed for ruminant production, especially in the areas where high quality fodder is not sufficient.

The nutritive value of maize stover is not only dependent upon climate conditions, cultivation practices (such as water and fertilizer management), storage methods and chemical composition, but also depended on variation in composition of morphological fractions. Tolera and Sundstøl (1999) reported that organic matter $(\mathrm{OM})$ and crude protein $(\mathrm{CP})$ digestion of maize stover in leaf blade were higher compared with stem. Tang et al. $(2006,2008)$ reported that CP content was higher but acid detergent fibre (ADF) content was lower in leaf blade than in stem. Except for morphological fractions, the nutritive value of stover is also related to the stage of harvesting. Tolera et al. (1998) and Pordesimo et al. (2005) reported that CP content of maize stover decreased but lignin and xylan increased with advancing the stage of maturity, and the soluble solids content in residual plant decreased. In addition to the harvest time and morphological fraction, the feeding value and digestibility of maize stover or maize silage were significantly affected by the variety factor (Tolera et al., 1999; Ettle and Schwarz, 2003; Tang et al., 2008). The digestibility of brown midrib varieties could be improved by their lower lignin content (Oba and Allen, 1999; Tjardes et al., 2000). Tolera et al. (1999) observed a significant varietal difference in grain and stover yield, and in situ dry matter (DM) degradability based on their observed eight maize varieties. Akay and Jackson (2001) and Akay et al. (2002) evaluated the nutritive value of NutriDense and waxy maize in dairy cows and sheep.

Generally, milky ripe (d 12 to $\mathrm{d} 17$ after tasseling) and dough stage (d 25 to $\mathrm{d} 31$ 
after tasseling) were considered as the main stage for fresh ear harvesting and ensiling. Sweet and waxy maize and fodder maize were generally planted to supply fresh ear for consumption and for ensiling, respectively. Conventional such as hybrid Rh208 and DK265 (Barrière et al., 2001, 2004), which were sown in Europe, and high oil maize were mainly planted as industrial stuff and feedstuffs. However, very few works have been devoted to studies of quality of morphological fractions related to early harvesting date. This study was, therefore, conducted to assess the proportion and quality of morphological fractions of five endosperm type maize harvested at two early maturity stages.

\section{MATERIAL AND METHODS}

This experiment was approved by the Animal Care Committee, Institute of Subtropical Agriculture (ISA), the Chinese Academy of Sciences, Changsha (P.R. China).

\section{Maize varieties}

Five maize hybrids, namely Kexiangyu 11 (conventional maize), Gaoyou 115 (high oil maize), Kexiangluoyu 1 (waxy maize), Huqing 1 (fodder maize) and Kexiangtianyu 1 (sweet maize) were used in this experiment. Kexiangluoyu 1 and Kexiangtianyu 1 are short and early maturing variety released by ISA, through intensive selection for increasing glutinousness and sweetness, respectively. Kexiangyu 11 developed by ISA, is a conventional maize variety. Gaoyou 115 is a variety containing higher oil concentration in grain, and developed in China Agriculture University in 1996. Huqing 1 is a hybrid variety used for ensiling.

\section{Planting, harvesting and preparation}

Five maize hybrids were sown at the $22^{\text {th }}$ of April 2005 and planted under similar agronomic condition on a same field at the experimental farm of ISA in southern China $\left(28^{\circ} 12^{\prime} \mathrm{N}\right.$ and $113^{\circ} 5^{\prime} \mathrm{E}$; altitude $\left.38 \mathrm{~m}\right)$. Ten whole plants of maize stover were collected in triplicate from three replicate plots and drawn from the standing crop at d 17 (maturity stage 1) and d 31 (maturity stage 2) after tasseling for all 5 varieties, respectively. Whole maize stovers were manually separated into 4 different morphological fractions, i.e. leaf blade, leaf sheath, stem and husk, then weighed to determine the proportions of morphological fractions. All samples were dried at $65^{\circ} \mathrm{C}$ in an oven and then milled through a $1-\mathrm{mm}$ sieve prior to chemical analysis and in vitro gas production measurements. 


\section{In vitro gas production}

Three rumen fistulated goats, which were fed $900 \mathrm{~g}$ of maize stover and $900 \mathrm{~g}$ of concentrate mix in equal portions twice daily and accessed water freely, were selected as the contributor of rumen fluid. The method modified by Tang et al. (2006) was selected to transact in vitro gas production. Approximately $200 \pm 10 \mathrm{mg}$ sample was weighed in triplicate into syringes of $100 \mathrm{ml}$. The syringes were pre-warmed at $39^{\circ} \mathrm{C}$ before the injection of $30 \pm 1 \mathrm{ml}$ rumen fluid-buffer mixture into each syringe and then placed in a shaking water bath (DSHZ-300, Taicang, Jiangsu, China) with 50 movements per min at $39^{\circ} \mathrm{C}$. Three syringes containing only incubation media were placed in the water bath and used as blanks to correct for the gas production due to the activity of the rumen fluid without a feed sample. Gas volume readings were recorded after 2, 4, 6, 12, 24, 36, 48, 60 and $72 \mathrm{~h}$ incubation. The data was fitted to the exponential equation (Blümmel and Ørskov, 1993):

$$
G P=a+b\left(1-e^{-c t}\right)
$$

where: $G P$ - gas production at time t, $a, b$ and $c$ are constants in the exponential equation, where $a$ - the intercept of gas production curve, $b$ - gas production of the insoluble but potentially fermentable fraction during time $(t), c$ - the rate of gas production of the ' $b$ ' fraction, $(a+b)$ - the potential gas production.

Volatile fatty acids (VFA) and $\mathrm{NH}_{3}-\mathrm{N}$ contents were determined after $72 \mathrm{~h}$ of incubation. Fermentation residue was filtered into the preweighed filter crucibles, dried at $105^{\circ} \mathrm{C}$ for $24 \mathrm{~h}$ and weighed, then ashed at $550^{\circ} \mathrm{C}$ for measuring in vitro organic matter disappearance (IVOMD).

\section{Chemical analysis}

Samples were dried at $105^{\circ} \mathrm{C}$ overnight and ignited at $550^{\circ} \mathrm{C}$ for $6 \mathrm{~h}$ for measuring DM and ash, respectively. Crude protein content was calculated as 6.25 $\times$ nitrogen $(\mathrm{N})$ which was determined using the Kjeldahl method (AOAC, 1999). Neutral detergent fibre (NDF) and acid detergent fibre (ADF) were determined using the method of Van Soest et al. (1991). NDF was assayed with the addition of a heat stable amylase, but without sodium sulphite, and is expressed inclusive of residual ash. ADF is expressed inclusive of residual ash. Total phosphorus (P) content was detected by molybdenum blue colorimetric method using an ultraviolet and visible spectrophotometer (UV8500-2, Tianmei, Shanghai, China) when the samples were digested by sulphuric acid and perchloric acid. 
A gas chromatograph (HP5890) was used for VFA analysis, and a HP-INNOWax column (30 $\mathrm{m}$ in length with a $0.25 \mathrm{~mm}$ i.d.) was used for the separation. The attenuation was set at nitrogen diffluent ratio 1:60, hydrogen flow $50 \mathrm{ml} / \mathrm{min}$, air flow $500 \mathrm{ml} / \mathrm{min}$, injector temperature $200^{\circ} \mathrm{C}$, column temperature $150^{\circ} \mathrm{C}$, detector temperature $200^{\circ} \mathrm{C}$. The relative response factor, representing the peak of each VFA, was calculated using the standard VFA mixture, which was chromatographed with each group of 10 samples. Total molar concentration was calculated by taking the sum of individual VFAs as $100 \%$. $\mathrm{NH}_{3}-\mathrm{N}$ was determined according to the procedure as described by Weatherburn (1967).

\section{Statistical analysis}

The statistical evaluation of the data was done by analysis of variance with the software package Statistical Analysis System (2001) using the GLM procedure. The model for analysis of the proportion of morphological fractions of the stover included the effects of variety, maturity stage and two-way interactions involving treatment main effects. Included in the model of chemical composition and in vitro fermentation parameters were variety, morphological fraction, maturity stage, and all two-way and three-way interactions involving treatment main effects. The statistical significance of the differences between means was tested using the Student-NewmanKeuls (SNK) test. Statistical significance was declared at $\mathrm{P} \leq 0.05$.

\section{RESULTS}

Morphological fraction proportion. The proportions of morphological fractions of five maize hybrids are presented in Table 1. Over one third of maize stover was stem, with leaf blade, husk and leaf sheath averagely accounting for $26.9,18.3$ and $14.2 \%$ of maize stover, respectively. Advanced maturity stage did not affect $(\mathrm{P}>0.05)$ the proportion of morphological fractions.

Maize hybrid variety had significant effects on the proportions of leaf blade, leaf sheath, stem and husk in maize stover. The high oil maize variety had higher leaf blade proportion than fodder, waxy and sweet maize variety (29.4 vs 26.7 , 25.9 and $25.6 \%$ ). The sweet maize variety had higher leaf sheath proportion than high oil, waxy and fodder maize variety. Stem proportion in fodder maize $(4.44 \%)$ was significantly higher than waxy, high oil and sweet maize varieties which were significantly higher than conventional variety. The highest proportion of husk in maize stover was observed in conventional maize variety $(21.8 \%)$, which was significantly higher than high oil and fodder maize (15.8 and 15.3\%). There were 
significant maturity stage $(\mathrm{M}) \times$ variety $(\mathrm{V})$ interaction effect on the proportions of leaf blade, leaf sheath and stem, while five varieties had inconsistent variation in morphological proportion with harvest date.

Table 1. Proportion (\%) of morphological fractions at different maturity stage for five maize varieties, DM basis

\begin{tabular}{|c|c|c|c|c|}
\hline Item & Leaf blade & Leaf sheath & Stem & Husk \\
\hline \multicolumn{5}{|l|}{$\overline{\text { Maturity stage }}$} \\
\hline stage 1 & 27.6 & 14.3 & 39.7 & 18.4 \\
\hline stage 2 & 26.3 & 14.0 & 41.5 & 18.2 \\
\hline SEM & 0.51 & 0.14 & 0.64 & 0.97 \\
\hline \multicolumn{5}{|l|}{ Maize variety } \\
\hline waxy & $25.9^{\mathrm{b}}$ & $14.0^{\mathrm{b}}$ & $41.1^{\mathrm{b}}$ & $19.0^{\mathrm{ab}}$ \\
\hline conventional & $27.2^{\mathrm{ab}}$ & $14.3^{\mathrm{ab}}$ & $36.7^{\mathrm{c}}$ & $21.8^{\mathrm{a}}$ \\
\hline fodder & $26.7^{\mathrm{b}}$ & $13.6^{\mathrm{b}}$ & $44.4^{\mathrm{a}}$ & $15.3^{\mathrm{b}}$ \\
\hline sweet & $25.6^{b}$ & $14.8^{\mathrm{a}}$ & $40.2^{\mathrm{b}}$ & $19.4^{\mathrm{ab}}$ \\
\hline high oil & $29.4^{\mathrm{a}}$ & $14.1^{\mathrm{b}}$ & $40.7^{\mathrm{b}}$ & $15.8^{\mathrm{b}}$ \\
\hline SEM & 0.81 & 0.23 & 1.01 & 1.53 \\
\hline \multicolumn{5}{|c|}{ Maturity stage $\times$ maize variety } \\
\hline $1 \times$ waxy & 26.5 & 14.5 & 38.5 & 20.5 \\
\hline $1 \times$ conventional & 25.5 & 13.4 & 38.6 & 22.5 \\
\hline $1 \times$ fodder & 28.4 & 13.6 & 42.5 & 15.5 \\
\hline $1 \times$ sweet & 28.1 & 15.8 & 40.2 & 15.9 \\
\hline $1 \times$ high oil & 29.6 & 14.2 & 38.8 & 17.4 \\
\hline $2 \times$ waxy & 25.2 & 13.5 & 43.8 & 17.5 \\
\hline $2 \times$ conventional & 28.9 & 15.2 & 34.7 & 21.2 \\
\hline $2 \times$ fodder & 25.0 & 13.6 & 46.3 & 15.1 \\
\hline $2 \times$ sweet & 23.0 & 13.8 & 40.2 & 23.0 \\
\hline $2 \times$ high oil & 29.2 & 14.0 & 42.5 & 14.3 \\
\hline SEM & 1.15 & 0.32 & 1.43 & 2.16 \\
\hline \multicolumn{5}{|l|}{ Significance } \\
\hline $\mathrm{M}$ & NS & NS & NS & NS \\
\hline $\mathrm{V}$ & $*$ & $*$ & $* * *$ & $*$ \\
\hline $\mathrm{M} \times \mathrm{V}$ & $*$ & $* * *$ & $*$ & NS \\
\hline
\end{tabular}

M - maturity stage effect; V - variety effect; $\mathrm{M} \times \mathrm{V}$ - interaction of maturity stage and variety; stage 1-17 days post-tasseling; stage 2 - 31 days post-tasseling; SEM - standard error of mean; NS - not significant; * $\mathrm{P} \leq 0.05 ; * * * \mathrm{P} \leq 0.001$

Chemical composition. A number of main effects of maturity stage, variety and morphological fraction on chemical composition of maize stover were given in Table 2. Maturity stage 2 resulted in the decline $(\mathrm{P}<0.05)$ of $\mathrm{CP}$ and $\mathrm{P}$ content from 96 and 2.13 to 82 and $1.86 \mathrm{~g} / \mathrm{kg}$ DM compared with maturity stage 1 .

Morphological fraction had a significant effect on chemical composition of maize stover. The OM content in husk ( $963 \mathrm{~g} / \mathrm{kg} \mathrm{DM})$ was significantly higher than that in leaf sheath $(899 \mathrm{~g} / \mathrm{kg} \mathrm{DM})$ and leaf blade $(873 \mathrm{~g} / \mathrm{kg} \mathrm{DM})$. Stem also 
Table 2. Chemical composition of morphological fractions for five variety maize stover harvested at two maturity stages

\begin{tabular}{|c|c|c|c|c|c|c|c|}
\hline \multirow{2}{*}{$\begin{array}{l}\text { Morphological } \\
\text { fraction }\end{array}$} & \multirow{2}{*}{ Variety } & \multirow{2}{*}{$\begin{array}{l}\text { Maturity } \\
\text { stage }\end{array}$} & \multicolumn{5}{|c|}{ Chemical composition, g/kg DM } \\
\hline & & & $\mathrm{OM}$ & $\mathrm{CP}$ & $\mathrm{P}$ & $\mathrm{NDF}$ & $\mathrm{ADF}$ \\
\hline \multirow[t]{10}{*}{ Leaf blade } & \multirow[t]{2}{*}{ Waxy } & 1 & 876 & 187 & 2.87 & 546 & 314 \\
\hline & & 2 & 857 & 160 & 2.57 & 554 & 339 \\
\hline & \multirow[t]{2}{*}{ Conventional } & 1 & 880 & 178 & 2.66 & 563 & 338 \\
\hline & & 2 & 867 & 156 & 2.85 & 552 & 355 \\
\hline & \multirow[t]{2}{*}{ Fodder } & 1 & 866 & 190 & 2.77 & 559 & 350 \\
\hline & & 2 & 879 & 165 & 2.50 & 559 & 351 \\
\hline & \multirow[t]{2}{*}{ Sweet } & 1 & 867 & 185 & 2.73 & 534 & 318 \\
\hline & & 2 & 859 & 165 & 2.17 & 551 & 340 \\
\hline & \multirow[t]{2}{*}{ High oil } & 1 & 891 & 192 & 2.97 & 521 & 303 \\
\hline & & 2 & 884 & 166 & 2.73 & 524 & 332 \\
\hline \multirow[t]{10}{*}{ Leaf sheath } & \multirow[t]{2}{*}{ Waxy } & 1 & 904 & 67 & 1.18 & 618 & 368 \\
\hline & & 2 & 904 & 55 & 1.15 & 635 & 356 \\
\hline & \multirow[t]{2}{*}{ Conventional } & 1 & 896 & 58 & 1.44 & 637 & 397 \\
\hline & & 2 & 902 & 50 & 1.36 & 631 & 377 \\
\hline & \multirow[t]{2}{*}{ Fodder } & 1 & 890 & 75 & 2.04 & 638 & 412 \\
\hline & & 2 & 907 & 57 & 2.07 & 576 & 355 \\
\hline & \multirow[t]{2}{*}{ Sweet } & 1 & 888 & 63 & 1.65 & 608 & 363 \\
\hline & & 2 & 896 & 59 & 1.40 & 651 & 379 \\
\hline & \multirow[t]{2}{*}{ High oil } & 1 & 903 & 66 & 1.65 & 594 & 368 \\
\hline & & 2 & 904 & 47 & 1.16 & 601 & 355 \\
\hline \multirow[t]{10}{*}{ Stem } & \multirow[t]{2}{*}{ Waxy } & 1 & 950 & 77 & 1.34 & 564 & 360 \\
\hline & & 2 & 959 & 62 & 1.21 & 523 & 331 \\
\hline & \multirow[t]{2}{*}{ Conventional } & 1 & 947 & 61 & 1.82 & 559 & 370 \\
\hline & & 2 & 938 & 53 & 1.35 & 539 & 365 \\
\hline & \multirow[t]{2}{*}{ Fodder } & 1 & 936 & 78 & 1.90 & 595 & 431 \\
\hline & & 2 & 954 & 70 & 1.60 & 539 & 354 \\
\hline & \multirow[t]{2}{*}{ Sweet } & 1 & 944 & 78 & 1.94 & 564 & 371 \\
\hline & & 2 & 948 & 73 & 1.55 & 553 & 372 \\
\hline & \multirow[t]{2}{*}{ High oil } & 1 & 945 & 61 & 1.85 & 581 & 382 \\
\hline & & 2 & 957 & 49 & 1.29 & 562 & 380 \\
\hline \multirow[t]{11}{*}{ Husk } & \multirow[t]{2}{*}{ Waxy } & 1 & 963 & 64 & 2.12 & 599 & 289 \\
\hline & & 2 & 961 & 50 & 1.50 & 682 & 322 \\
\hline & Conventional & 1 & 958 & 56 & 2.28 & 630 & 316 \\
\hline & & 2 & 964 & 50 & 1.99 & 662 & 345 \\
\hline & Fodder & 1 & 967 & 58 & 2.43 & 588 & 303 \\
\hline & & 2 & 969 & 53 & 2.66 & 615 & 297 \\
\hline & Sweet & 1 & 962 & 66 & 2.52 & 560 & 291 \\
\hline & & 2 & 961 & 56 & 2.21 & 645 & 332 \\
\hline & High oil & 1 & 965 & 59 & 2.53 & 607 & 311 \\
\hline & & 2 & 958 & 47 & 1.80 & 663 & 353 \\
\hline & & SEM & 6.83 & 5.64 & 0.208 & 19.85 & 12.48 \\
\hline
\end{tabular}


Table 2. continued

\begin{tabular}{llcccccc}
\hline Morphological & \multirow{2}{*}{$\begin{array}{l}\text { Variety } \\
\text { fraction }\end{array}$} & Stage & & \multicolumn{5}{c}{ Chemical composition, g/kg DM } \\
\cline { 5 - 8 } Significance & $\mathrm{M}$ & $\mathrm{NS}$ & $* * *$ & CP & P & NDF & ADF \\
& $\mathrm{F}$ & $* * *$ & $* * *$ & $* * *$ & NS & NS & NS \\
& $\mathrm{V}$ & $*$ & $* * *$ & $* * *$ & $\mathrm{NS}$ & $* *$ & $* *$ \\
& $\mathrm{M} \times \mathrm{V}$ & $\mathrm{NS}$ & $\mathrm{NS}$ & $\mathrm{NS}$ & $\mathrm{NS}$ & $* * *$ & $* * *$ \\
& $\mathrm{~F} \times \mathrm{V}$ & $\mathrm{NS}$ & $\mathrm{NS}$ & $\mathrm{NS}$ & $\mathrm{NS}$ & $*$ & $*$ \\
& $\mathrm{M} \times \mathrm{F}$ & $\mathrm{NS}$ & $*$ & $\mathrm{NS}$ & $* * *$ & $* * *$ & $* * *$ \\
& $\mathrm{M} \times \mathrm{F} \times \mathrm{V}$ & $\mathrm{NS}$ & $\mathrm{NS}$ & $\mathrm{NS}$ & $\mathrm{NS}$ & $\mathrm{NS}$ & $\mathrm{NS}$ \\
\hline
\end{tabular}

OM - organic matter; CP - crude protein; P - phosphorous; NDF - neutral detergent fibre; ADF acid detergent fibre; stage 1-17 days post-tasseling; stage 2-31 days post-tasseling; SEM - standard error of mean; M - maturity stage effect; V - variety effect; $\mathrm{F}$ - morphological fraction effect; $\mathrm{M} \times \mathrm{V}$ - interaction of maturity stage and variety; $\mathrm{V} \times \mathrm{F}$ - interaction of variety and morphological fraction; $\mathrm{M} \times \mathrm{F}$ - interaction of maturity stage and morphological fraction; $\mathrm{M} \times \mathrm{V} \times \mathrm{F}$ - interaction of maturity stage and variety and morphological fraction; NS - not significant; ${ }^{*} \mathrm{P} \leq 0.05$; $* * \mathrm{P} \leq 0.01$; $* * * \mathrm{P} \leq 0.001$

had a higher $(\mathrm{P}<0.05) \mathrm{OM}$ content than in leaf sheath which was significantly higher $(\mathrm{P}<0.05)$ than in leaf blade. The $\mathrm{CP}$ content of four morphological fractions, except for leaf blade, was below $67 \mathrm{~g} / \mathrm{kg}$ DM. The highest $\mathrm{P}$ content was observed in the part of leaf blade $(2.68 \mathrm{~g} / \mathrm{kg} \mathrm{DM})$ which was significantly higher $(\mathrm{P}<0.05)$ than that of husk $(2.20 \mathrm{~g} / \mathrm{kg} \mathrm{DM})$ which was in turn higher $(\mathrm{P}<0.05)$ than those of stem and leaf sheath (1.59 and $1.51 \mathrm{~g} / \mathrm{kg} \mathrm{DM})$. The parts of leaf blade and stem had lower $(\mathrm{P}<0.05)$ NDF content than those parts of leaf sheath and husk. Leaf sheath and stem had higher $(\mathrm{P}<0.05)$ ADF content than that of leaf blade and husk.

Organic matter content of stover parts from high oil was higher $(\mathrm{P}<0.05)$ than that of sweet variety. Morphological fractions from fodder and sweet were higher $(\mathrm{P}<0.05)$ in $\mathrm{CP}$ content $(93$ and $93 \mathrm{~g} / \mathrm{kg} \mathrm{DM})$ than that of high oil and conventional ( 86 and $83 \mathrm{~g} / \mathrm{kg} \mathrm{DM}$ ). The ADF content in five varieties showed the following ranking order: conventional $>$ fodder $>$ high oil $>$ sweet $>$ waxy. There was significant $\mathrm{M} \times \mathrm{V}, \mathrm{F} \times \mathrm{V}$ and $\mathrm{M} \times \mathrm{F}$ interaction on $\mathrm{ADF}$ content of stover. Maturity also interacted $(\mathrm{P}<0.05)$ with morphological fractions for $\mathrm{CP}$ and NDF content of maize stover.

In vitro fermentation characteristics. Tables 3 and 4 show the in vitro fermentation characteristics of morphological fractions for five varieties of maize stovers harvested at two stages. Advanced maturity stage increased $(\mathrm{P}<0.001)$ the value of $a$, but decreased $(\mathrm{P}<0.01)$ the values of $b$ and $a+b$ of maize stover. The TVFA concentration of maize stover decreased $(\mathrm{P}<0.001)$ with the increase of maturity.

Stem had a higher $(\mathrm{P}<0.05) a$ value than husk which was in turn higher $(\mathrm{P}<0.05)$ than leaf sheath and leaf blade. The highest $b, c, a+b$ and IVOMD 
Table 3. In vitro fermentation parameters of morphological fraction from five varieties harvested at two maturity stages

\begin{tabular}{|c|c|c|c|c|c|c|c|}
\hline \multirow{2}{*}{$\begin{array}{l}\text { Morphological } \\
\text { fraction }\end{array}$} & \multirow{2}{*}{ Variety } & \multirow{2}{*}{$\begin{array}{c}\text { Maturity } \\
\text { stage }\end{array}$} & \multicolumn{4}{|c|}{ Gas production parameters } & \multirow{2}{*}{$\begin{array}{c}\text { IVOMD } \\
\% \\
\end{array}$} \\
\hline & & & $a, \mathrm{ml}$ & $b, \mathrm{ml}$ & $c, \mathrm{ml} / \mathrm{h}$ & $a+b, \mathrm{ml}$ & \\
\hline \multirow[t]{10}{*}{ Leaf blade } & \multirow[t]{2}{*}{ Waxy } & 1 & 1.77 & 51.7 & 0.068 & 53.4 & 51.7 \\
\hline & & 2 & 3.39 & 47.0 & 0.052 & 50.4 & 56.9 \\
\hline & \multirow[t]{2}{*}{ Conventional } & 1 & 1.09 & 49.4 & 0.043 & 50.5 & 73.8 \\
\hline & & 2 & 1.21 & 43.7 & 0.056 & 44.9 & 62.3 \\
\hline & \multirow[t]{2}{*}{ Fodder } & 1 & -0.31 & 52.2 & 0.053 & 51.9 & 56.7 \\
\hline & & 2 & 5.18 & 46.1 & 0.046 & 51.3 & 59.6 \\
\hline & \multirow[t]{2}{*}{ Sweet } & 1 & 2.55 & 45.7 & 0.060 & 48.2 & 61.5 \\
\hline & & 2 & 3.79 & 39.5 & 0.043 & 43.3 & 63.0 \\
\hline & \multirow[t]{2}{*}{ High oil } & 1 & 2.47 & 48.8 & 0.055 & 51.3 & 60.6 \\
\hline & & 2 & 4.02 & 42.7 & 0.044 & 46.7 & 67.9 \\
\hline \multirow[t]{10}{*}{ Leaf sheath } & \multirow[t]{2}{*}{ Waxy } & 1 & 2.24 & 54.3 & 0.061 & 56.5 & 70.6 \\
\hline & & 2 & 5.61 & 50.0 & 0.060 & 55.7 & 66.1 \\
\hline & \multirow[t]{2}{*}{ Conventional } & 1 & -0.46 & 53.4 & 0.080 & 52.9 & 75.9 \\
\hline & & 2 & 7.75 & 46.2 & 0.081 & 54.0 & 64.2 \\
\hline & \multirow[t]{2}{*}{ Fodder } & 1 & -1.44 & 54.3 & 0.063 & 52.8 & 61.7 \\
\hline & & 2 & 6.74 & 49.3 & 0.068 & 56.1 & 66.8 \\
\hline & \multirow[t]{2}{*}{ Sweet } & 1 & 6.96 & 47.0 & 0.069 & 53.9 & 64.4 \\
\hline & & 2 & 3.06 & 49.3 & 0.069 & 52.4 & 64.9 \\
\hline & \multirow[t]{2}{*}{ High oil } & 1 & 3.46 & 49.6 & 0.055 & 53.1 & 67.2 \\
\hline & & 2 & 6.97 & 46.3 & 0.067 & 53.2 & 58.1 \\
\hline \multirow[t]{10}{*}{ Stem } & \multirow{2}{*}{ Waxy } & 1 & 11.76 & 49.2 & 0.067 & 61.0 & 51.8 \\
\hline & & 2 & 16.15 & 46.3 & 0.055 & 62.4 & 69.4 \\
\hline & \multirow[t]{2}{*}{ Conventional } & 1 & 12.97 & 36.2 & 0.046 & 49.2 & 59.4 \\
\hline & & 2 & 11.22 & 35.3 & 0.061 & 46.6 & 55.4 \\
\hline & \multirow[t]{2}{*}{ Fodder } & 1 & 3.81 & 40.2 & 0.046 & 44.0 & 50.6 \\
\hline & & 2 & 13.29 & 36.4 & 0.049 & 49.7 & 57.9 \\
\hline & \multirow[t]{2}{*}{ Sweet } & 1 & 11.28 & 37.2 & 0.049 & 48.5 & 59.1 \\
\hline & & 2 & 7.40 & 39.3 & 0.061 & 46.7 & 57.3 \\
\hline & \multirow[t]{2}{*}{ High oil } & 1 & 10.90 & 39.4 & 0.046 & 50.3 & 56.7 \\
\hline & & 2 & 14.81 & 36.6 & 0.059 & 51.4 & 58.7 \\
\hline \multirow[t]{11}{*}{ Husk } & Waxy & 1 & 8.82 & 63.8 & 0.074 & 72.6 & 75.6 \\
\hline & & 2 & 5.61 & 67.1 & 0.071 & 72.7 & 60.5 \\
\hline & Conventional & 1 & 8.52 & 59.7 & 0.052 & 68.2 & 78.9 \\
\hline & & 2 & 3.40 & 53.2 & 0.071 & 56.6 & 81.2 \\
\hline & Fodder & 1 & 5.82 & 62.6 & 0.073 & 68.5 & 76.1 \\
\hline & & 2 & 5.24 & 64.9 & 0.070 & 70.2 & 77.1 \\
\hline & Sweet & 1 & 7.61 & 58.5 & 0.077 & 66.1 & 81.9 \\
\hline & & 2 & 4.62 & 59.8 & 0.069 & 64.4 & 81.2 \\
\hline & High oil & 1 & 12.35 & 54.7 & 0.064 & 67.1 & 74.6 \\
\hline & & 2 & 4.54 & 55.9 & 0.060 & 60.4 & 75.2 \\
\hline & & SEM & 1.11 & 1.67 & 0.0049 & 1.49 & 2.80 \\
\hline
\end{tabular}


Table 3. continued

\begin{tabular}{|c|c|c|c|c|c|c|c|}
\hline \multirow{2}{*}{$\begin{array}{l}\text { Morphological } \\
\text { fraction }\end{array}$} & \multirow{2}{*}{ Variety } & \multirow{2}{*}{$\begin{array}{c}\text { Maturity } \\
\text { stage }\end{array}$} & \multicolumn{4}{|c|}{ Gas production parameters } & \multirow{2}{*}{$\begin{array}{c}\text { IVOMD } \\
\%\end{array}$} \\
\hline & & & $a, \mathrm{ml}$ & $b, \mathrm{ml}$ & $c, \mathrm{ml} / \mathrm{h}$ & $a+b, \mathrm{ml}$ & \\
\hline \multirow[t]{7}{*}{ Significance } & $\mathrm{M}$ & & $* * *$ & $* * *$ & NS & $* *$ & NS \\
\hline & $\mathrm{F}$ & & $* * *$ & $* * *$ & $* * *$ & $* * *$ & $* * *$ \\
\hline & $\mathrm{V}$ & & $* * *$ & $* * *$ & * & $* * *$ & $* * *$ \\
\hline & $\mathrm{M} \times \mathrm{V}$ & & $* *$ & NS & $* *$ & $* * *$ & $* *$ \\
\hline & $\mathrm{F} \times \mathrm{V}$ & & $* * *$ & $* * *$ & $* * *$ & $* * *$ & $* * *$ \\
\hline & $\mathrm{M} \times \mathrm{F}$ & & $* * *$ & $* * *$ & $*$ & $* * *$ & $* *$ \\
\hline & $\mathrm{M} \times \mathrm{F} \times \mathrm{V}$ & & $* * *$ & NS & NS & NS & $* * *$ \\
\hline
\end{tabular}

$a$ - the intercept of gas production curve; $b$ - the proportion of gas production during time ( $\mathrm{t}$ ); $c$ - the rate of gas production of the ' $b$ ' fraction; IVDMD - in vitro dry matter disappearance; IVOMD - in vitro organic matter disappearance; stage 1-17 days post-tasseling; stage 2-31 days post-tasseling; SEM - standard error of mean; M - maturity stage effect; V - variety effect; $\mathrm{F}$ - morphological fraction effect; $\mathrm{M} \times \mathrm{V}$ - interaction of maturity stage and variety; $\mathrm{V} \times \mathrm{F}$ : interaction of variety and morphological fraction; $\mathrm{M} \times \mathrm{F}$ - interaction of maturity stage and morphological fraction; $\mathrm{M} \times \mathrm{V} \times \mathrm{F}$ - interaction of maturity stage and variety and morphological fraction; NS - not significant; * $\mathrm{P} \leq 0.05 ; * * \mathrm{P} \leq 0.01 ; * * * \mathrm{P} \leq 0.001$

values were found in husk $(60.0 \mathrm{ml}, 0.068 \mathrm{ml} / \mathrm{h}, 66.7 \mathrm{ml}$, and $76.2 \%)$, and the lowest value of $b$ and IVOMD were observed in stem (39.6 $\mathrm{ml}$ and 57.6\%) which were significantly lower $(\mathrm{P}<0.05)$ than those of the other morphological fractions. For $c$ and $a+b$, the lowest values were observed in leaf blade which were significantly lower $(\mathrm{P}<0.05)$ than that of leaf sheath and husk. Base on IVOMD value, the morphological fractions showed the following ranking order: husk $>$ leaf sheath $>$ leaf blade $>$ stem. The highest molar proportions of propionate and butyrate were detected in husk and stem, respectively.

Variety affected $(\mathrm{P}<0.05)$ the in vitro fermentation parameters of maize stover. High oil was higher $(\mathrm{P}<0.01)$ in $a$ value than waxy which was in turn higher $(\mathrm{P}<0.001)$ than that of sweet, conventional and fodder. The highest values of $b, c$ and $a+b$ were noted in waxy which was higher $(\mathrm{P}<0.001)$ than that of conventional, sweet and high oil in $b$ and $a+b$ values, and higher $(\mathrm{P}<0.001)$ than fodder and high oil in gas production rate. Conventional and waxy had the highest and the lowest IVOMD value, respectively. The highest ammonia nitrogen concentration was detected in conventional, which was higher $(\mathrm{P}<0.001)$ than that of other varieties. High oil was higher $(\mathrm{P}<0.001)$ in TVFA concentration than conventional and waxy which were in turn higher $(\mathrm{P}<0.05)$ than that of fodder and sweet. Molar proportion of acetate was higher $(\mathrm{P}<0.01)$ for waxy, conventional, high oil and fodder than that of sweet. Morphological fractions from sweet and fodder were higher $(\mathrm{P}<0.001)$ in molar proportion of propionate. Stover parts from sweet had the highest molar proportion of butyrate but the lowest ratio of acetate to propionate. Maturity stage interacted $(\mathrm{P}<0.05)$ with variety and morphological 
Table 4. $\mathrm{NH}_{3}-\mathrm{N}$ and TVFA concentration and volatile fatty acid molar proportion of morphological fractions from five varieties harvested at two maturity stages

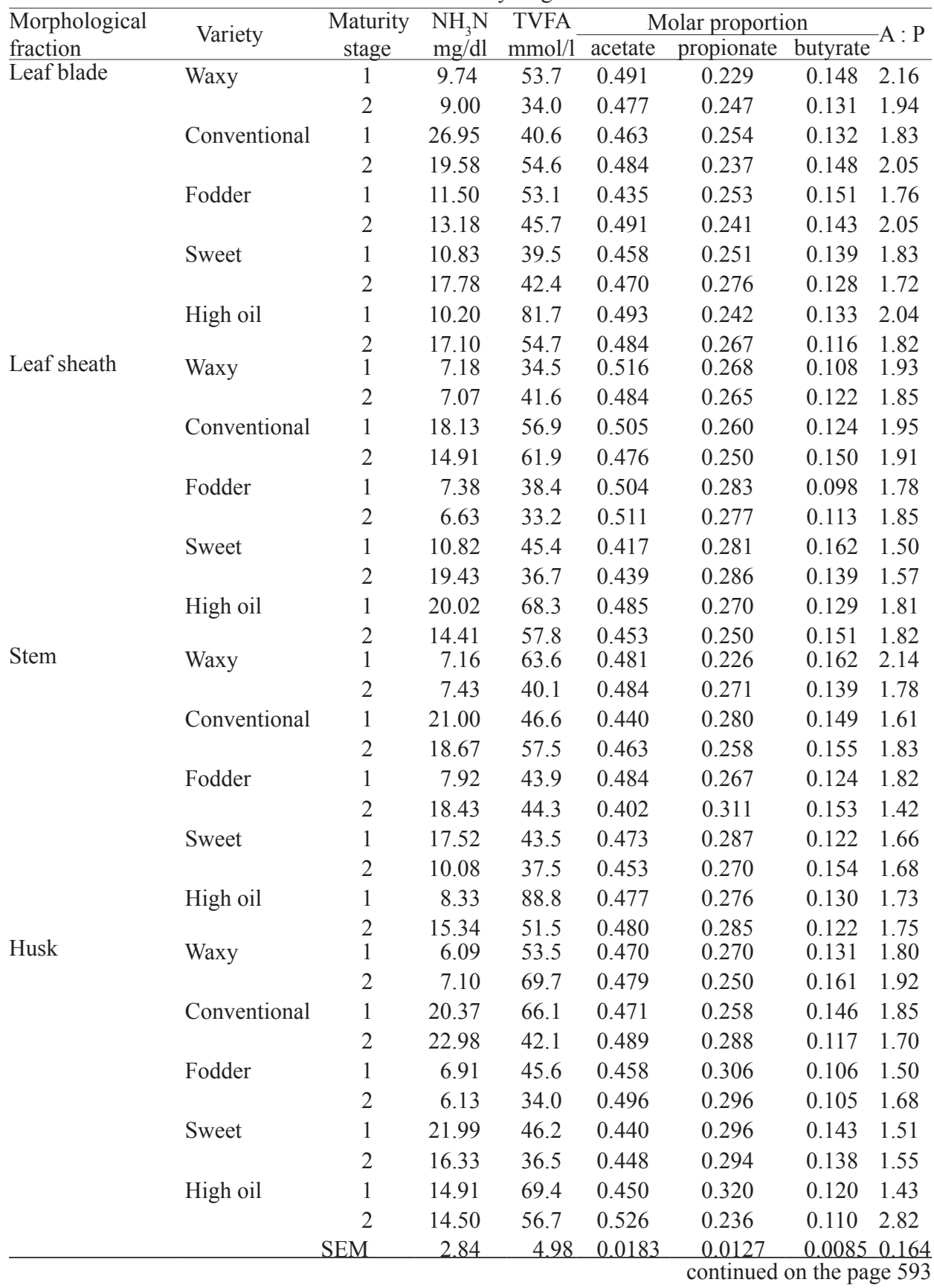


Table 4. continued

\begin{tabular}{|c|c|c|c|c|c|c|c|c|}
\hline \multirow{2}{*}{$\begin{array}{l}\text { Morphological } \\
\text { fraction }\end{array}$} & \multirow{2}{*}{ Variety } & \multirow{2}{*}{$\begin{array}{l}\text { Maturity } \\
\text { stage }\end{array}$} & \multirow{2}{*}{$\begin{array}{l}\mathrm{NH}_{3} \mathrm{~N} \\
\mathrm{mg} / \mathrm{dl}\end{array}$} & \multirow{2}{*}{$\begin{array}{l}\text { TVFA } \\
\mathrm{mmol} / 1\end{array}$} & \multicolumn{3}{|c|}{ Molar proportion } & \multirow{2}{*}{$\mathrm{A}: \mathrm{P}$} \\
\hline & & & & & acetate & propionate & butyrate & \\
\hline \multirow[t]{7}{*}{ Significance } & $\mathrm{M}$ & & NS & $* * *$ & NS & NS & NS & NS \\
\hline & $\mathrm{F}$ & & NS & NS & NS & *** & ** & NS \\
\hline & V & & $* * *$ & $* * *$ & $* *$ & $* * *$ & $* * *$ & $* * *$ \\
\hline & $\mathrm{M} \times \mathrm{V}$ & & NS & $* * *$ & NS & NS & NS & NS \\
\hline & $\mathrm{F} \times \mathrm{V}$ & & NS & $* * *$ & $*$ & NS & $* * *$ & NS \\
\hline & $\mathrm{M} \times \mathrm{F}$ & & NS & NS & $*$ & $*$ & NS & $*$ \\
\hline & $\mathrm{M} \times \mathrm{F} \times \mathrm{V}$ & & $*$ & $* * *$ & $*$ & $* *$ & $* * *$ & $* *$ \\
\hline
\end{tabular}

TVFA - total volatile fatty acid; A:P - the ratio of acetic acid and propionic acid; stage 1- 17 days post-tasseling; stage 2 - 31 days post-tasseling; SEM - standard error of mean; M - maturity stage effect; V - variety effect; $\mathrm{F}$ - morphological fraction effect; $\mathrm{M} \times \mathrm{V}$ - interaction of maturity stage and variety; $\mathrm{V} \times \mathrm{F}$ - interaction of variety and morphological fraction; $\mathrm{M} \times \mathrm{F}$ - interaction of maturity stage and morphological fraction; $\mathrm{M} \times \mathrm{V} \times \mathrm{F}$ - interaction of maturity stage and variety and morphological fraction; NS - not significant; * $\mathrm{P} \leq 0.05 ; * * \mathrm{P} \leq 0.01 ; * * * \mathrm{P} \leq 0.001$

fraction for all gas production parameters except for $b$ value, TVFA and molar proportion of acetate and propionate. Morphological fraction also interacted $(\mathrm{P}<0.05)$ with variety for all gas production parameters, TVFA and molar proportion of acetate and butyrate. A three-way interaction $(\mathrm{P}<0.05)$ for $a$, IVOMD, $\mathrm{NH}_{3}-\mathrm{N}$ and TVFA concentration, molar proportions of VFAs and $\mathrm{A}: \mathrm{P}$ ratio was also detected.

\section{DISCUSSION}

The difference among five genotype varieties in proportion of leaf, stem and husk fractions confirmed the result that gene variation caused the alteration of morphological composition for maize stover. Over the harvest date, stem fraction possessed the highest proportion in whole stover and increased with the increasing of harvest date, and the proportions of leaf fraction (including leaf blade and leaf sheath) and husk fraction decreased with the increasing of harvest date are in agreement with the previous studies (Russell, 1986; Tolera and Sundstøl, 1999). Interestingly, the proportion of leaf (leaf blade and leaf sheath) increased and stem decreased for conventional, while it decreased and increased, respectively, for the rest varieties with the increase of maturity. The reason is unclear, but this may imply that the decline in stover quality was not greater for conventional than the other varieties. The proportion of leaf fraction (including leaf blade and leaf sheath) in the present study comprised a similar proportion compared with stem (Table 1) indicated that the nutritive value of maize stover are not only dependent upon the quality of the stem, but also dependent upon the quality of leaf fraction. 
Average content of fibre (NDF and ADF) in stover parts increased and the content of CP decreased with increasing the stage of maturity is consistent with the previous study on maize stover (Russell, 1986; Tolera et al., 1998; Tolera and Sundstøl, 1999). Darby and Lauer (2002) also reported that CP content of maize stover decreased from 100 to $67 \mathrm{~g} / \mathrm{kg} \mathrm{DM}$ at the first and the last harvest date, and the content of ADF and NDF exhibited an increasing with the increasing of maturity stage. The result implies that the quality of maize stover may decrease with the advance of maturity. On the other hand, the decrease in potential gas production $(a+b)$, and $b$ value (the fermentation of the insoluble but potentially fermentable fraction) with the increasing of maturity stage were consistent with the previous studies (Tolera et al., 1998; Tolera and Sundstøl, 1999). A decline in IVOMD with increasing the stage of maturity was in agreement with the findings of Irlbeck et al. (1993), and may ascribe to the increase of fibre content in stover and the decrease in degradability of cell wall constituents. These results indicated that the nutritive value or quality of maize stover could be declined by the advance of maturity.

The results of present study revealed that maize stover fractions from new maize varieties (e.g., waxy, sweet, fodder and high oil) had higher CP content and lower fibre contents (NDF and ADF) than those from conventional variety. In previous studies (Lacount et al., 1995; Akay and Jackson, 2001), the waxy, high oil and fodder maize varieties also had higher $\mathrm{CP}$ and lower NDF and ADF content than conventional variety. Mustafa et al. (2004) reported that NDF and ADF contents of sweet maize variety stover are 571 and $301 \mathrm{~g} / \mathrm{kg}$ DM, respectively, lower than the results of conventional variety reported in present study, but the content of CP $(99 \mathrm{~g} / \mathrm{kg} \mathrm{DM})$ is higher than that in present study (Table 2). Higher CP and lower NDF content for fodder and sweet than conventional and waxy indicated that more nitrogen and readily digestible nutrients could be supplied by fodder and sweet than conventional and waxy for ruminants.

Potential gas production and IVOMD reflected the digestibility of forage. The decline in the value of $a+b$ was greater for conventional than for high oil, sweet and waxy with the increase of maturity, and the advanced maturity stage decreased IVOMD of conventional, but did not affect IVOMD value of high oil, sweet and waxy which indicated that the nutritive quality of conventional was more readily affected by maturity stage than new maize varieties. Increasing in potential gas production and IVOMD for fodder (Table 3 ) with the increase of maturity is likely related to the decrease of fibre content (NDF and ADF; Table 2) with the increasing of maturity stage, and further implies that the readily digestible nutrient was higher for fodder than for the others in advanced maturity stage. The molar proportion of propionate for new maize varieties (except for waxy variety) was higher than conventional variety indicated that the new maize varieties could supply more 
energy for ruminant than conventional variety. The new maize varieties, although, were used in different purpose in production conditions. The results in present study revealed that the stover of the new maize varieties were high quality forage for ruminants. New maize varieties could supply more digestible nutrients for ruminants than conventional in advanced maturity stage.

The highest CP and lowest NDF content in leaf blade compared with other parts are consistent with the previous studies on other cereal straws and maize stover (Tan et al., 1995; Tolera and Sundstøl, 1999; Tang et al., 2008). Higher CP content in leaf blade, stem and husk fractions of waxy, fodder and sweet than conventional indicated that these new varieties was higher in ability of nitrogen enrichment than conventional. Relatively higher values of $b, a+b$ and $c$ for husk and $a$ value for stem in present study was consistent with the previous studies (Tolera and Sundstøl, 1999; Tang et al., 2006). Leaf blade from five varieties (except for conventional) had similar $a$ value, but the stem from waxy, high oil and conventional had higher $a$ value than sweet and fodder. This may result from the leaf blade from high oil, fodder, sweet and waxy had similar OM content, but the content of OM in stem of conventional, waxy and high oil was higher than that of sweet and fodder. The stem and husk fractions from waxy had the highest $b$ value was likely related to these fractions from waxy had the highest hemicellulose content. Potential gas production of stem and husk from waxy was the highest, while it was the similar in leaf blade and leaf sheath for five varieties indicated that the degradability was higher for leaf blade from waxy than from the other varieties. The values of potential gas production could not rank the morphological fractions in the same order as IVOMD. This disagreement may ascribe to the gas production resulted from the fermentation of protein was less than from the fermentation of carbohydrate (Cone and van Gelder, 1999).

As shown in Table 4, the average concentration of ammonia nitrogen in leaf blade was higher than that other fractions. It may attribute to crude protein in other fractions was lower than that of leaf blade (Tables 2 and 4). But the concentration of ammonia nitrogen in different maize varieties was not in agreement with the change of $\mathrm{CP}$ contents. A reason for the disagreement between $\mathrm{NH}_{3}-\mathrm{N}$ and $\mathrm{CP}$ content may be a different $\mathrm{CP}$ degradability. The content of TVFA was also not rank the morphological fractions in the same order as the result of Tolera and Sundstøl (1999). In present study, the fractions of husk and the varieties of high oil and conventional had higher TVFA content than other fractions or varieties, which may ascribe to the higher NDF content in these fractions or varieties than other fractions or varieties (Blümmel and Becker, 1997). The molar proportion of propionate exceeded 0.250 for four fractions, which is higher than that of Tolera and Sundstøl (1999). The inconsistent result may ascribe to the difference of maize varieties. Significant interactions among $\mathrm{M} \times \mathrm{F} \times \mathrm{V}$ on content and 
molar proportion of VFA indicated that differences in the nutritive value of maize stovers may not only dependent on the actual differences within morphological parts, but also on the differences in the proportions of morphological fractions with different maturity stage.

Fermentation parameters differed between individual fractions, especially between different hybrids indicated that the individual fractions differed in degradability, and this may result the difference in fermentation parameters between hybrids. Although it is impossible to fractionate maize stover in production conditions, the stover fed ruminants consists of the fractions mentioned above. The variation in quality or proportion of fractions may change the nutritive value of whole maize stover. Understanding the nutritive value of morphological fractions is helpful to improve the nutritive value of maize stover by selecting the suitable harvesting date or increasing the proportion of leaf and husk fractions, which had higher degradation, in breeding.

\section{CONCLUSIONS}

Maize variety and the stage of maturity significantly affected the proportion of morphological fractions. The delay of harvesting date resulted in reducing the proportion of leaf blades, leaf sheath and husk and the contents of crude protein (CP) and phosphorus with concomitant increase in stem proportion and fibre content. Conventional variety had lower $\mathrm{CP}$ and higher fibre content compared with other varieties. Fermentation parameters of $b, a+b$, in vitro organic matter disappearance, and total volatile fatty acids decreased with the increase of maturity. Morphological fractions differed in gas production rate and potential gas production in the following order: husk $>$ leaf sheath $>$ stem $>$ leaf blade. Waxy had the highest values of $b, c$ and $a+b$, and high oil, waxy and sweet had the highest total volatile fatty acids concentration, molar proportion of acetate and propionate, respectively. It was concluded that the nutritive value of maize stover was not only dependent on the differences within morphological fractions, but also on maturity stage and genotype of maize.

\section{ACKNOWLEDGEMENTS}

Grace Tayo gratefully acknowledges the support of a postdoctoral fellowship grant from Chinese Academy of Sciences (CAS) and the Academy of Sciences of the Developing World (TWAS). 


\section{REFERENCES}

Akay V., Jackson J.A.J., 2001. Effects of NutriDense and waxy maize hybrids on the rumen fermentation, digestibility and lactational performance of dairy cows. J. Dairy Sci. 84, 16981706

Akay V., Jackson J.A.J., Harmon D.L., 2002. NutriDense and waxy maize hybrids: effects on site and extent of disappearance of nutrients in sheep. J. Anim. Sci. 80, 1335-1343

AOAC, 1999. Association of Official Analytical Chemists, Official Methods of Analysis. 16 ${ }^{\text {th }}$ Edition. Washington, DC

Barrière Y., Dias Gonçalves G., Emile J.C., Lefèvre B., 2004. Higher intake of DK265 corn silage by dairy cattle. J. Dairy Sci. 87, 1439-1445

Barrière Y., Vérité R., Brunschwig P., Surault F., Emile J.C., 2001. Feeding value of corn silage estimated with sheep and dairy cows is not altered by genetic incorporation of Bt176 resistance to Ostrinia nubilalis. J. Dairy Sci. 84, 1863-1871

Blümmel M., Becker K., 1997. The degradability characteristics of fifty-four roughages and roughage neutral detergent fibres as described by in vitro gas production and their relationship to voluntary feed intake. Brit. J. Nutr. 77, 757-768

Blümmel M., Ørskov E.R., 1993. Comparison of in vitro gas production and nylon bag degradability of roughages in predicting feed intake in cattle. Anim. Feed Sci. Tech. 40, 109-119

Cone J.W., van Gelder A.H., 1999. Influence of protein fermentation on gas production profiles. Anim. Feed Sci. Tech. 76, 251-264

Darby H.M., Lauer J.G., 2002. Harvest date and hybrid influence on corn forage yield, quality and preservation. Agron. J. 94, 559-566

Ettle T., Schwarz F.J., 2003. Effect of corn variety harvested at different maturity stages on feeding value and performance of dairy cows. Anim. Res. 52, 337-349

Irlbeck N.A., Russell J.R., Hallauer A.R., Buxton D.R., 1993. Nutritive value and ensiling characteristics of maize stover as influenced by hybrid maturity and generation, plant density and harvest date. Anim. Feed Sci. Tech. 41, 51-64

Lacount D.W., Drackley J.K., Cicela T.M., Clark J.H., 1995. High oil corn as silage or grain for dairy cows during an entire lactation. J. Dairy Sci. 78, 1745-1754

Mustafa A.F., Hassanat F., Berthiaume R.R., 2004. In situ forestomach and intestinal nutrient digestibilities of sweet corn residues. Anim. Feed Sci. Tech. 114, 287-293

Oba M., Allen M.S., 1999. Effects of brown midrib 3 mutation in corn silage on dry matter intake and productivity of high yielding dairy cows. J. Dairy Sci. 82, 135-142

Pordesimo L.O., Hames B.R., Sokhansanj S., Edens W.C., 2005. Variation in corn stover composition and enery content with crop maturity. Biomass Bioenerg. 28, 366-374

Russell J.R., 1986. Influence of harvest date on the nutritive value and ensiling characteristics of maize stover. Anim. Feed Sci. Tech. 14, 11-27

SAS, 2001. SAS User's Guide: Version 8.2 Edition. SAS Institute Inc. Cary, NC

Tan Z.L., Chen H.P., He L.H., Fang R.J., Xing T.X., 1995. Variation in the nutritional characteristics of wheat straw. Anim. Feed Sci. Tech. 53, 337-344

Tang S., Tan Z., Zhou C., Jiang H., Jiang Y., Sheng L., 2006. A comparison of in vitro fermentation characteristics of different botanical fractions of mature maize stover. J. Anim. Feed Sci. 15, 505-515

Tang S.X., Gan J., Sheng L.X., Tan Z.L., Tayo G.O., Sun Z.H., Wang M., Ren G.P., 2008. Morphological fractions, chemical composition and in vitro fermentation characteristics of maize stover of five genotypes. Animal 2, 1772-1779. doi:1710.1017/S1751731108003121 
Tjardes K.E., Buskirk D.D., Allen M.S., Bourquin L.D., Rust S.R., 2000. Brown midrib-3 corn silage improves digestion but not performance of growing beef steers. J. Anim. Sci. 78, $2957-$ 2965

Tolera A., Berg T., Sundstøl F., 1999. The effect of variety on maize grain and crop residue yield and nutritive value of the stover. Anim. Feed Sci. Tech. 79, 165-177

Tolera A., Sundstøl F., 1999. Morphological fractions of maize stover harvested at different stages of grain maturity and nutritive value of different fractions of the stover. Anim. Feed Sci. Tech. $81,1-16$

Tolera A., Sundstøl F., Said A.N., 1998. The effect of stage of maturity on yield and quality of maize grain and stover. Anim. Feed Sci. Tech. 75, 157-168

Van Soest P.J., Robertson J.B., Lewis B.A., 1991. Methods for dietary fiber, neutral detergent fiber, and nonstarch polysaccharides in relation to animal nutrition. J. Dairy Sci. 74, 3583-3597

Weatherburn M.W., 1967. Phenol-hypochlorite reaction for determination of ammonia. Anal. Chem. 39, 971-974 